\title{
Is It Possible to Revitalize a Dying Language? An Examination of Attempts to Halt the Decline of Irish
}

\author{
Michael Bradley \\ Okinawa Christian Junior College, Nishihara, Okinawa, Japan \\ Email: mbradley@ocjc.ac.jp
}

Received 7 August 2014; revised 2 September 2014; accepted 9 September 2014

Copyright (C) 2014 by author and Scientific Research Publishing Inc.

This work is licensed under the Creative Commons Attribution International License (CC BY).

http://creativecommons.org/licenses/by/4.0/

\begin{abstract}
This paper evaluates the attempts to revitalize the indigenous language of Ireland. It examines how the number of native Irish speakers declined under British rule, and how this trend continued even after independence, when Irish was declared the country's official language. Successive Irish governments have used two main strategies to reverse language shift. The first was to protect the small Irish speaking areas in the west of the country, the Gaeltacht. The second was to rely on schools elsewhere to produce new generations of fluent Irish speakers. By the 1970s it was apparent that neither policy was working. However since then, somewhat improbably, an increasing number of people have begun to use Irish, both inside and outside the Gaeltacht. This paper examines whether this revival constitutes reverse language shift. In particular, it asks to what extent Irish is now being passed on as a mother tongue to a new generation of children.
\end{abstract}

\section{Keywords}

Irish, Reverse Language Shift, Gaeltacht

\section{Introduction}

Research suggests that half of the world's languages will become extinct before the end of this century (Crystal, 1997). With so many tongues facing language shift, what hope is there for reviving languages which are already moribund? For at least one linguist, "there is no unequivocal answer to this question" (Tsunoda, 2006). For another, Joshua Fishman (Fishman, 1991), Reverse Language Shift (RLS) is only possible if the endangered minority language is once again passed on to children as their mother tongue. Very often minority languages disappear from countries where the powerful speak a different language. This is not the case in Ireland. Not only 
have governments (since independence in 1921) not been hostile to Irish, they have vowed to revitalize it. As such, Ireland provides a fascinating case study of what is possible when it comes to language maintenance in apparently favorable circumstances.

In the year Ireland became independent Eamonn de Valera, (who would later become Prime Minister and then President) grandiloquently declared, "Ireland with its language and without its freedom is preferable to Ireland with its freedom and without its language" (Edwards, 2010). From the outset, however, there existed a gap between political rhetoric and policy in the new state. The task of reversing centuries of language shift was left almost entirely to the public education system - a policy which, it can be said after almost a century, has clearly failed. So much so that linguist Joshua Fishman coined the term "Irelandization" as an example of how not to achieve Reverse Language Shift (Fishman, 1991). And yet there are still encouraging signs for this Gaelic language. Census results indicate that the numbers of Irish speakers in the western Gaeltacht are holding up (2011 Census) while there has been a boom in the number of private Irish medium schools, or Gaelscoileanna, across the rest of the country (Gaelscoileanna, 2014). This paper will chart the course of language shift in Ireland and examine the various efforts to halt and even reverse that shift.

\section{How English First Displaced Irish}

It is perhaps best to first look at the causes of language shift in Ireland, to get an idea of the magnitude of the task which has faced Irish lawmakers over the past century. As folklore would have it, English was foisted on the unwilling Irish by an aggressive imperialistic Britain from the Middle Ages onwards. Kearns described how "repressive British penal codes that outlawed the use of the vernacular caused it to ebb away at an ever increasing rate during the $17^{\text {th }}$ century” (Kearns, 1974). The Catholic Church, Daniel O Connell and the famine were all ascribed a role in the language's demise. Undoubtedly, colonization was the central reason for language shift (Edwards, 2010) but the manner in which it occurred was more subtle than popular belief would suggest. The acquiescence of the population in the spread of English was probably a more salient factor than any government decree. There is more than a little truth in the anti-Irish diatribe of English journalist Sydney Brooks at the turn of the last century, when he complained that the Irish "have tried to cast upon the broad British doorstep the responsibility for the decay of Gaelic... It is impossible to stamp out a language when the people are determined to keep alive" (Brooks, 1908).

English was first introduced into Ireland, along with French, as early as 1169 by Anglo-Norman invaders. Neither language, however, gained a foothold at that time and the new settlers were rapidly Gaelicised (Hindley, 1990). That the 1336 Statutes of Kilkenny (which forbade settlers from using Irish) were felt necessary, is a measure of how few people spoke English. In fact, English was seldom used outside the Pale (the small area around Dublin) for the next four hundred years. Irish's linguistic hegemony was finally undone by the plantations of the $16^{\text {th }}$ and $17^{\text {th }}$ centuries, when migrants from the North of England and the Scottish lowlands, defended by Crown troops, were settled on confiscated land in Ireland. Increasingly, those who controlled the economic and political power throughout the island spoke English. Whatever few opportunities there were for advancement were bound up with knowledge of English which, "was seen as the language of commerce, the path to prosperity" (Durkacz quoted by Edwards, 2010). By 1800 the majority of the population still spoke Irish (Edwards, 2010), but the Act of Union in that year (which officially joined Britain and Ireland), further strengthened the need for English and it became the language of instruction in the National School system, established in 1831. By 1851 half a million children were attending these schools. It is anachronistic to suggest that parents allowed their children to be educated in English only reluctantly. Presumably like all parents, they wanted their offspring to be as well qualified as possible for whatever opportunities existed, be they across the sea in Britain or further afield in the New World.

Daniel O'Connell spoke in English when addressing the huge political rallies in the 1830s and 1840s. For him, there was little political gain to be had from using Irish, which had yet to acquire any nationalistic connotations. O'Connell's choice of English demonstrates how widely the language was understood. It also shows his realization that the authorities could not so easily ignore the disaffected if they shared the same language. Pragmatism of one kind or another underlay the individual choices made over time by hundreds of thousands to switch to English. It was clearly more socially prestigious than Irish, being the language of the Catholic Church, education, and the rich and powerful. Inexorably, English spread westwards from the relatively prosperous East. The mid$18^{\text {th }}$ Century potato famine consolidated its grip—of the two million people who died or emigrated, the majority 
came from the impoverished Irish speaking regions of Munster and Connaught. By 1881 Irish was the mother tongue of only $28.4 \%$ of the population (ibid). The writer of that year's census noted, "Within relatively a few years (sic) Irish will have taken its place among the languages that have ceased to exist" (ibid).

\section{The Gaelic League Highlights the Plight of Irish}

It was not until the late $19^{\text {th }}$ century that the imminent disappearance of Irish caused any real concern among the population at large. The Gaelic League, established under Douglas Hyde in 1892 turned language revival into a political issue. Influenced by German Romanticism, the League emphasized Ireland's unique cultural identity vis-a-vis that of England, providing the rationale for why Irish should be restored—a rationale that has remained remarkably constant ever since.

The $18^{\text {th }}$ Century German philosopher Johann Herder believed that language and nationhood were inextricably bound together; one could not exist without the other. "Has a nation anything more precious than the language of it fathers?” he asked (Oakes, 2001). Drawing on such philosophy, Hyde (who in 1938 became the first president of Ireland) argued that the Irish language was central to Irish identity while English was the language of modernization and repellent materialism. "The losing of it [Irish] is our greatest blow, and the sorest stroke that the rapid Anglicization of Ireland has inflicted upon us” (Hyde, 1892). His message evidently struck a chord and the League attracted over 50000 members by its height in 1904. It established language classes throughout the country and persuaded the government to make Irish the language of instruction in Gaeltacht schools. It also successfully campaigned to make Irish proficiency a prerequisite for entry to the newly founded National University. In retrospect, the League's failing was that it never analyzed how native English speakers would transmit Irish to their children as a mother tongue- - how Irish could make the quantum leap from being a second language to a first language - the holy grail of Reverse Language Shift.

By 1912 the Gaelic League had been overshadowed by the struggle for independence and was a spent force. When the Irish Free State (later to become the Republic of Ireland) was established in 1921, Irish politicians were for the first time apparently in a position to control the destiny of the Irish language. Despite the huge shift from Irish to English over the previous centuries, it was the former which became "the official language of Ireland.” Judging by census figures alone, the gamble paid off. In 1881 just under a million people were, "able to speak Irish” and by 1911 this had declined to 553,717 (Hindley, 1990). However, a century later the numbers had more than tripled to 1,774,437 (2011 Census). During the same period the population as a whole grew from just over three million to just over four and a half million. On closer scrutiny, the achievement is less impressive. Census data not only failed to distinguish between native speakers and second language learners, it also failed to define what was meant by being "able to speak Irish". Furthermore, it failed to take account of the strong emotional attachment to Irish which led some respondents to exaggerate their proficiency. In short the census results may well have been misleading when it came to assessing the numbers of Irish speakers.

\section{How Irish Governments Tried to Revive Irish}

The continued existence of any language depends upon the existence of a critical mass of native speakers. Ultimately, governments can only claim success in terms of language maintenance if they have expanded or at least halted the decline in the number of native speakers. Since independence successive Irish governments have attempted to do this in two ways-one, by trying to reintroduce Irish as the main language in the English speaking part of the country, (the Galltacht) and two, by attempting to preserve the Irish speaking Gaeltacht on the peripheral western seaboard.

\section{Government Strategy in English Speaking Areas}

Rhetoric aside, little practical effort was ever made to promote Irish in public life in the Irish state. It was never used as the language of parliament or of any government department apart from education, where it was used only occasionally (ibid). Up until 1973 Irish proficiency was a requirement for anyone applying to work in the civil service but in practice the vast majority of employees never used it (Edwards, 2010). It was a similar situation in the police, army and legal profession (Hindley, 1990). One policy instrument alone was relied on to enact the shift from English to Irish - the National School system.

The State's first government was much influenced by the advice of Fr. Timothy Corcoran of the Irish Nation- 
al Teacher's Association. He believed schools could restore the native language, “... even without aid from the home" (Titley, 1983). Accordingly, in the early days of the state, Irish was used as the medium of instruction in infant classes and in geography, history and singing lessons for older children. It later became the official language of instruction in every class where teachers were "competent to use it" (ibid). In practice, how much of the curriculum was taught through Irish was left up to each parish. In 1939 a record 704 schools (of around 5000) taught exclusively through Irish, while a further 50\% taught partly through Irish (MacNamara, 1966). However, disenchantment set in (as primary and high school graduates realized there was no communicative need for Irish) and by 1960 the Department of Education was actively discouraging the use of Irish in infant classes. Mac Namara's study a few years later further undermined classroom bilingualism arguing that it had a deleterious effect on children's English, whilst failing to improve their Irish (Edwards, 2010). In 1970 the use of Irish in infants' classes stopped. By 2006 a government report was concluding that there had been a "substantial decline in achievement in Irish listening and Irish speaking in ordinary schools since 1985” (Harris, 2006).

Clearly, Irish public education failed to deliver Reverse Language Shift. How or why children were expected to use Irish outside school when society in general did not was never made explicit. Perhaps some felt that the language was inextricably bound up with national identity and that patriotism would ensure its survival. Evidently, this was not enough when other markers of Irishness existed, (like residence in the Irish State, or belonging to the Catholic Church.) Many linguists argue that languages only survive when there is a communicative need for them. There never was for Irish in the English speaking Galltacht. MacNamara tells the anecdote of how as a little boy he was upbraided by a shopkeeper for not using Irish. Somewhat puzzled he asked his sister, "Is Irish for talking?” (quoted by Dorian, 1987). As the Irish government belatedly acknowledged in a 1966 White Paper, "It would be unrealistic" to expect English to be displaced quickly because of "our geographical position and the pattern of our economic and social relations," or to put it another way, "It is simply not possible to bring about widespread language shift when the appeal is made on the basis of abstractions like cultural heritage or tradition" (Edwards, 2007). This at least was the linguistic orthodoxy before events over the past three decades began to call it into question.

\section{The Rise of All Irish Schools}

Notwithstanding the absence of any communicative need for Irish in the Galltacht, there has been an explosion in the popularity of Irish medium education across the Republic of Ireland. In 1979 there were 23 Irish medium All Irish Schools (AISs or Gaelscoileanna) outside the Gaeltacht, 12 of them in Dublin. In total they catered to 1100 families (O'Riagain, 1979). Today the situation has been transformed. There are currently over 40,000 pupils at AISs in the Republic of Ireland (excluding the Gaeltacht.) Of these, just over 32,000 attend 144 primary schools, while the remainder is at secondary schools (Gaelscoileanna, 2014).

Of course it is easy to overestimate the impact that Irish medium schools may have on the wider linguistic community. For one thing, parents do not always send their children to AISs specifically to learn Irish. Often, they may simply be attracted by small class sizes, the enthusiasm of teachers, and the school's overall academic reputation. Back in 1979 O'Riagain found that only 11\% of parents at the two AISs in working class areas (Ballymun and Blanchardstown) sent their children there for “language reasons” (O’Riagain, 1979). Harris's (2006) study did not explicitly ask parents why they sent their children to AISs but much can be inferred from the parents' attitudes. 55\% said they let their "child know Irish is important" as opposed to the $44 \%$ who left it up to the child "to develop his own attitude to Irish" (Harris, 2006). Similarly, 57\% of AIS parents described themselves as being "very favorable" to the language.

On the face of it, it would seem that in recent years more parents have been sending their children to AISs for language reasons than was the case 35 years ago. However, being favorable to a language doesn't necessarily translate into using that language at home. Harris found that just $6 \%$ of AIS parents classed themselves as having a "native speaker ability" in Irish. This was the same percentage as the number of parents who "always" or "very often" spoke to their child in Irish. In contrast, the vast majority (77\%) used mostly English at home (ibid). Harris was not altogether dejected by these findings as AIS were bringing together parents with relatively high levels of ability in Irish, "who might otherwise be rather thinly dispersed in the population," leading to, "the possibility that adult and family Irish speaking networks will develop" (ibid).

Although, Irish is not being spoken in the homes of many AIS pupils, the schools may still be playing a significant role in engendering RLS. Harris noted that some 95\% of AIS graduates, irrespective of their family 
background, attained communicative "mastery" in the language (ibid) and as such were in a position, if they chose, to conduct their domestic lives through Irish. Linguist Joshua Fishman, who coined the term, argued that Reverse Language Shift would only happen if people started to again use the endangered language at home, and more particularly, if they passed it on as the mother tongue to subsequent generations (Fishman, 1991).

Fishman argued that for RLS to succeed it had to progress through eight stages, the most crucial of which was stage three: "only after the intergenerational transmission system is in good operational order can the higher order agencies be concentrated upon" (ibid). His contention was that children would only be comfortable using the minority language if they were introduced to it in the secure surroundings of the home. Education by itself, he said, was not capable of engendering RLS since it is not, "sufficiently affect laden, intimacy and identity focused or societally binding for such purposes" (ibid). In the Irish context, it would seem that unless the cycle of learning the language as a second language can be broken, students will have forgotten the Irish they learned at school by the time they come to rear their own children.

As has already been noted, the country's National Schools proved themselves incapable of engendering RLS. The question is whether those graduating from AISs today are different in kind from the thousands of fluent Irish speakers who, over the years, emerged from National Schools and then went on to use English in their everyday lives. Are AIS graduates sufficiently motivated, ideologically driven, and committed to the language, to do what very few of their predecessors have done and switch to Irish as their home language. Harris is relatively optimistic; "by producing substantial numbers of pupils with high levels of proficiency, all-Irish schools may be crossing a crucial threshold in terms of contributing to the formation of Irish speaking networks outside Gaeltacht areas” (Harris, 2006). Whilst there is anecdotal evidence of an increasing amount of Irish being spoken in pubs, cafes, and workplaces, it is still unclear to what extent Irish is being used in homes. Assuming Fishman is correct, and home use is the key to RLS, then further academic research is required to quantify just how many families in the Galltacht are now rearing their children in Irish.

\section{The Gaeltacht}

Let us turn now to the second policy instrument which successive Irish governments have relied on to save Irish - the maintenance of the Gaeltacht. From 1921 onwards, it has been accepted that the future of Irish depends on the protection of its native speaker heartlands. Such places could provide inspiration to Irish learners elsewhere in the country, as well as giving them opportunities to practice the language when they visited on holiday. Up until just over a century ago, "the Gaeltacht covered all of the western third of Ireland, and its population exceeded one and a half million” (Kearns, 1974). Since then there has been a drastic contraction, leaving only three main Gaeltacht areas in Donegal, Connemara, and West Kerry; all isolated communities on the Atlantic seaboard. Such isolation and attendant poverty, have historically led many young people to leave the Gaeltacht, jeopardizing its very existence. By the middle of the last century it became clear to policy makers that if the Gaeltacht were to be preserved, if only in demographic terms, then migration needed to be curbed. For many years the only financial incentive to stay in the Gaeltacht was a small grant, the deontas, paid to Irish speakers. Realizing it also had to provide jobs, in 1958 the government promised to promote rural industry in the Irish speaking West (ibid). Initial efforts were hampered by poor infrastructure and inevitably the State was forced to take over many of the projects (Williams, 1988) Things improved with the creation of Údarás na Gaeltachta in 1980. It was given responsibility for the economic, social and cultural development of the Gaeltacht. Over 7000 people are currently employed full time in companies supported by Údarás. These include fish processing plants, a television production facility, and an engineering company (Údarás na Gaeltachta, 2014).

Economic investment has done much to stem the tide of migration from the Gaeltacht. The population has risen from 78,000 in 1961 to just over 100,000 in 2011 (Central Statistics Office, 2014). As O’Cinneide had previously written, "the demographic survival of the Gaeltacht seems assured but its existence as a Gaelic speaking population is dangerously imperiled" (O'Cinneide, 1985). He voiced a widespread fear that the domains for Irish would be further shrunk as some of the companies established by Údarás recruited English speaking managers, (because, they said, they were unable to find suitably qualified Irish speakers.) Another factor undermining the use of Irish was that of returning former emigrants, bringing back non-Irish speaking partners and children. Hindley saw little prospect of Gaelicising such incomers in the absence of "a substantial territorial base in which Irish has unchallenged dominance" (Hindley, 1990). Describing the Gaeltacht as being "only flimsily insulated" from English, Hindley estimated in 1991 there were only about 10,000 genuine "Irish 
speakers" left. He went on to predict that the language would have no native speakers "in one, or at most, two generations" (ibid).

Events have proved Hindley wrong, at least in terms of timing. In 2002 the census reported a total of 62157 "Irish speakers" living in the Gaeltacht, a figure which increased slightly to 66238 in 2011. Hindley has in the past disputed the validity of using census figures where respondents assess their own linguistic ability (Hindley, 1990). In this, he may be right. If, as the 2011 census records indicate, almost $70 \%$ of Gaeltacht residents were Irish speakers, it would seem natural to expect that a similar percentage of Gaeltacht school children would come from Irish speaking homes. In fact, Harris discovered that only 55\% of school children in the Gaeltacht were from homes where only some Irish was spoken (Harris, 2006). More tellingly, only $37 \%$ of the parents of Gaeltacht school children classified themselves as "native Irish Speakers" (ibid). Such statistics chimed with the views of Gaeltacht teachers, the majority of whom felt there had been a decline in their pupils' standard of Irish over the previous 15 years (ibid). It seems indisputable that despite an increase in the overall population, the Gaeltacht's core of native speakers continues to shrink, a fact acknowledged by the former government appointed Irish Language Commissioner, Ronan O’Domhnaill, who warned that "unless radical remedial action is taken" the days of Irish "as the Gaeltacht's main language of the home and community are numbered" (O'Domhnaill, 2014).

If the Gaeltacht does disappear, it is difficult to see how Irish could survive, even if the exponential growth of AISs in the rest of the country persisted. "A growth in what has been called 'secondary bilingualism' does not mean the same thing for the language as an increase in native speakers" (Edwards, 2010). If the chain of intergenerational transmission of Irish from native speaker to native speaker were to be broken, much obscure vocabulary and many lesser-used grammatical structures would be lost. The fledgling Irish speaking communities in Dublin and elsewhere would have nowhere to turn for reference or clarification. The headmaster of an Irish language secondary school in Belfast expressed the problem like this, "When the monolinguists go, the language loses a lot because anything could be expressed in the language in very simple terms. But when you lose the monolinguists it's a translation from English sometimes and with English mixed through it. If there are more learners than native speakers, then it is a very different type of language” (Mac Giolla Ghunna, 2014). A similar point was made by Maguire (Maguire, 1990) who studied a small Irish speaking urban Gaeltacht in Belfast in the late 1980s. She found that the Irish spoken in the Shaws Road community differed in significant ways from the traditional variety spoken in the Donegal Gaeltacht. There was a reduction in the case system and an obvious influence of English on vocabulary, morphology and syntax. Lexical items were often borrowed from English, "onto which Irish morphological segments are fixed" (ibid).

The prospects for the future of the Gaeltacht are not, however, completely bleak. Harris reports that of those Gaeltacht school children who came from all English households, 42\% still attained mastery in Irish by the time they graduated (Harris, 2006). If at least some of these graduates decide to use Irish in their own homes, there is a chance that the number of native speakers will grow, allowing the Gaeltacht to recover some of the ground it has lost over the past century. History is of course against such an outcome-with the exception of Hebrew, there really isn't any precedent for a language as endangered as Irish making a comeback. (The case of Hebrew, involving the mass migration of millions of people from different linguistic backgrounds, collectively traumatized by the holocaust, relocating in an already inhabited country, is profoundly different to the Irish situation.) Still, just as the explosion of AISs confounded the predictions of many linguists, there is a chance, albeit a small one, that there will be a significant shift across the country towards the use of Irish in the home. Already, there are indications that a growing number of families are communicating through Irish. The 2011 census found that 17330 three and four year old children (outside the Gaeltacht) could "speak Irish," almost twice the number reported in the 2002 census (Central Statistics Office, 2014).

\section{Conclusion}

Even if Irish were to make a comeback as the language of the home, it is unclear how long it could survive when English is the language of not just the wider community but also of television (aside from one Irish language channel) and cyberspace. Only two university courses in the entire country, other than dedicated language courses, are taught through Irish - Law and Irish (University College Cork) and Irish and Journalism (Dublin City University) (Irish Universities Association Website, 2014). Few Irish speakers believe that this kind of diglossia, where Irish is used at home and English everywhere else is sustainable in the long term. As MacA- 
goain said, "the reason that Irish doesn't survive very well in everyday life is...because there is nothing to do with it” (quoted by Edwards, 2010). With this in mind perhaps, the last Irish Language Commissioner shortly before his resignation called "for the right to conduct business with the State in Irish because the provision of such services is key to the survival of the language” (O’Domhnaill, 2014). Clearly, despite the growth in Irish medium education and the numerical expansion of the Gaeltacht, impressive as they both are, the battle to secure the future of Irish is a long way from being won.

\section{References}

Brooks, S. (1908). The New Ireland: VI. The Gaelic League. The North American Review, 188, 262-272.

Central Statistics Office (2014). http://www.cso.ie/en/

Crystal, D. (1997). The Cambridge Encyclopedia Of Language. Cambridge: Cambridge University Press.

Edwards, J. (2007). Back from the Brink: The Revival of Endangered Languages. In M. Hellinger, \& A. Pauwels (Eds.), Handbook of Language and Communication. Berlin: Walter de Gruyter,

Edwards, J. (2010). Minority Languages and Group Identity. Amsterdam: John Benjamins. http://dx.doi.org/10.1075/impact.27

Dorian, N. C. (1987). The Value of Language Maintenance Efforts Which Are Unlikely to Succeed. International Journal of the Sociology of Language, 1987, 57-68.

Gaelscoileanna Website (2014). http://www.gaelscoileanna.ie/?lang=en

Harris, J. (2006). Irish in Primary Schools. Dublin: Government Stationary Office.

Hindley, R. (1990). The Death of the Irish Language. London: Routledge.

Hyde, D. (1892). The Necessity for De-Anglicising Ireland. http://www.thefuture.ie/wp-content/uploads/1892/11/1892-11-25-The-Necessity-for-De-Anglicising-Ireland.pdf

Irish Universities Association Website (2014). http://www.iua.ie/

Fishman, J. (1991). Reversing Language Shift: Theory and Practice of Assistance to Threatened Languages. Clevedon: Multilingual Matters.

Kearns, K. C. (1974). Resuscitation of the Irish Gaeltacht. Geographical Review, 64, 82-110.

Maguire, G. (1990). Our Own Language. Clevedon: Multilingual Matters.

MacNamara, J. (1966). Bilingualism and Primary Education. Edinburgh: Edinburgh University Press.

Micheál Mac Giolla Ghunna (Principal of Coláiste Feirste) Interview 7/03/2014.

O’Cinneide, M. S. (1985). Industrialisation and Linguistic Change among Gaelic Speaking Communities in the West of Ireland. Language Problems and Language Planning. Austin, TX: University of Texas Press.

O’Domhnaill, R. (2014). Why Minding Our Language Is a Priority. The Irish Times, 24 March 2014.

O’Riagian, P. (1979). All Irish Primary Schools in the Dublin Area. Dublin: Institiud Teangeolaiochta Eireann.

Oakes, L. (2001). Language and National Identity. Philadelphia, PA: John Benjamins Publishing. http://dx.doi.org/10.1075/impact.13

Titley, E. B. (1983). Church, State and the Control of Schooling in Ireland 1900-1944. Dublin: Gill and Macmillan.

Tsunoda, T. (2006). Language Endangerment and Language Revitalization. Berlin: Mouton de Gruyter.

Údarás na Gaeltachta Website (2014). http://www.udaras.ie/en

Williams, C. H. (1988). Language Planning and Regional Development: Lessons from the Irish Gaeltacht. In C. H. Williams (Ed.), Language in Geographic Context (pp. 267-230). Clevedon: Multilingual Matters. 
Scientific Research Publishing (SCIRP) is one of the largest Open Access journal publishers. It is currently publishing more than 200 open access, online, peer-reviewed journals covering a wide range of academic disciplines. SCIRP serves the worldwide academic communities and contributes to the progress and application of science with its publication.

Other selected journals from SCIRP are listed as below. Submit your manuscript to us via either submit@scirp.org or Online Submission Portal.
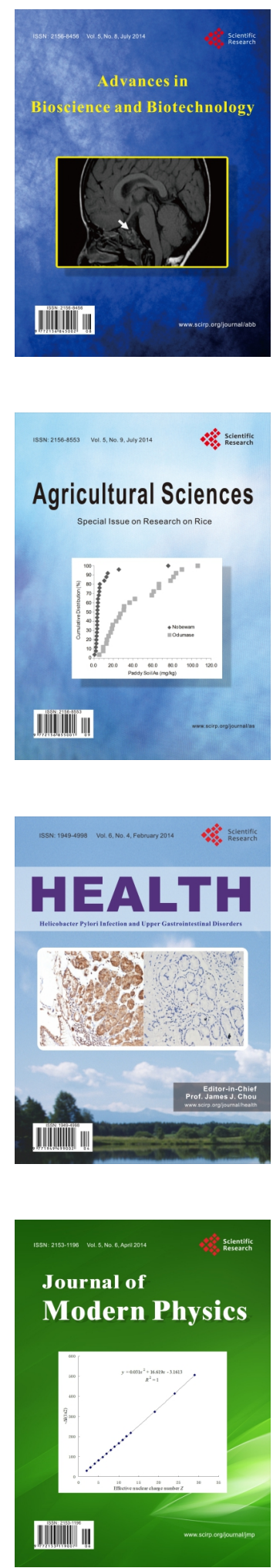
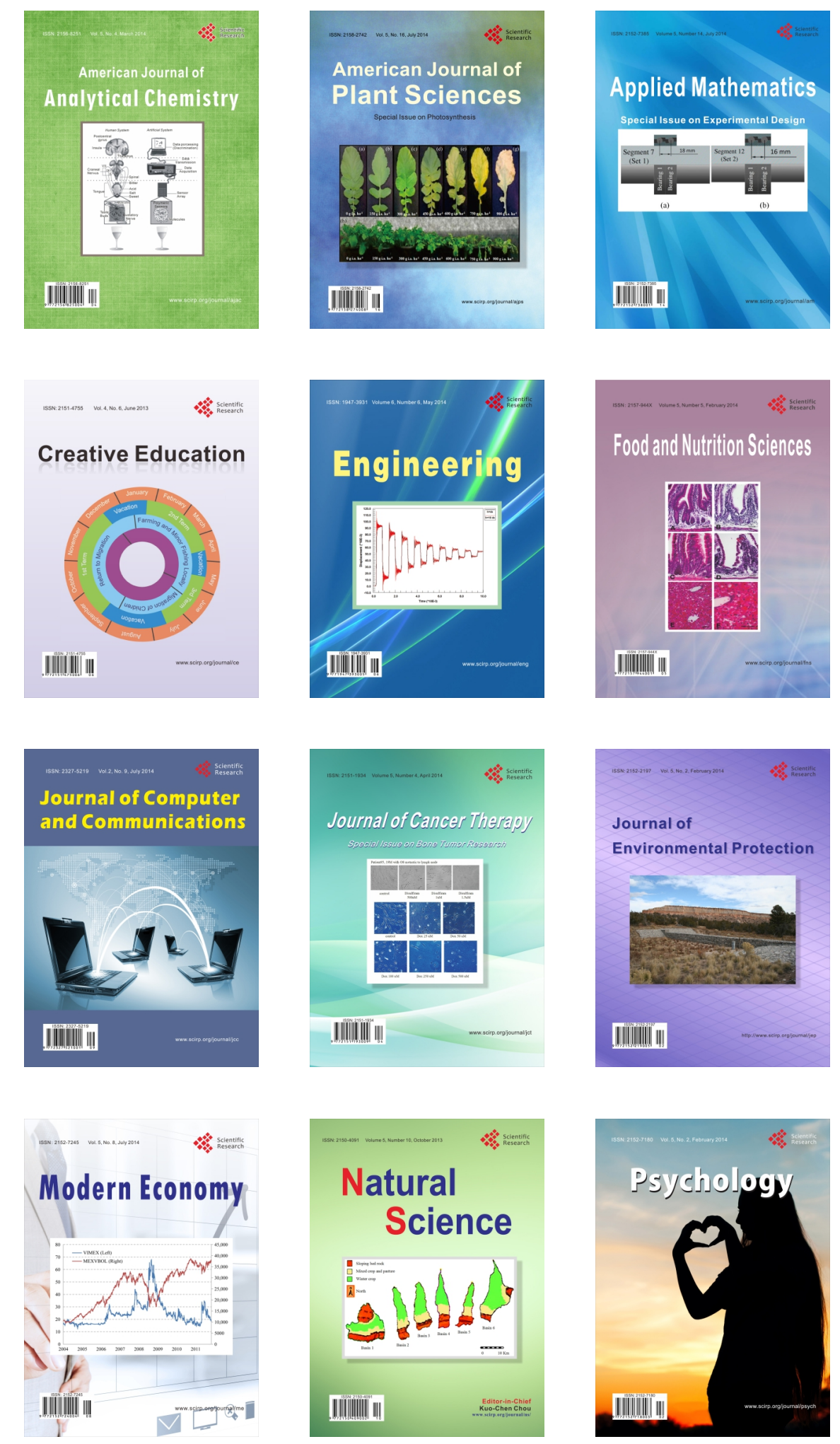